\title{
EDITORIAL
}

\author{
SARENA ABDULLAH \\ Universiti Sains Malaysia
}

\section{Artistic practices in contemporary Asia}

Welcome to Art $\mathcal{E}$ the Public Sphere Volume 7, Issue 1, one of the few art journals that focuses on the complex web of regional and international challenges that confront local cultural, religious and political forms of artistic practices in the public sphere. Fundamentally, the journal frames its niche area of examining the critical relationship towards the traditional and conventional debates about art, especially in the context of it being part of or engaged with the public/public sphere.

In the past decades, the global geopolitical economy has shifted its focus from Europe to United States, and then in the new millennium, to Asia. Under the geographical premise of Asia, this issue focuses on the selection of papers that address the artistic practice that linked art to the broader shifts of political, social and public spheres. The contemporary artistic practices in Asia have long evolved and have grown exponentially since the 1990s, with the increasing regional biennials and triennials, the establishment of new contemporary art museums and the success of various Asian artists. This encouraged the establishment of various alternative artistic practices that reflected the everevolving and mutative artistic practices in contemporary Asia.

Globalization, mobility and the threats and opportunities that new technologies have expanded are also reflected in such artistic practices. Globalization enables the potentially breaking down of boundaries and revolutionizes the way artists think and see. Technologies, low-cost carriers, international 
art events and exhibitions such as biennials and triennials inevitably allow and boost the changing artistic practices that encourage engagement among artists and the public. Mobilization among artists and the advance of communication technology have both contributed to the spread of knowledge and information at an epidemic rate - such situations are deemed unavoidable today. These factors, whether we like it or not, have changed the nature of art practice since the 1990s.

Despite these inevitable phenomena, local cultures in various parts of Asia adjusted well to globalization. Although many artists refer to various resources from the 'global culture' to enhance their own practices, they are still strongly influenced by the contemporary political and social changes within the boundary of the nation-state. Such was the context of this call for papers that were selected for this issue. This issue comprises five articles on Turkey, Malaysia, China/Hong Kong, Korea and Indonesia, respectively. These papers examine the local, regional and international factors that have impacted and shaped the local art world or artistic practices. The essays assembled fall into two discrete categories: the first section deals with the examination of events and the alternative artistic practices; whilst the second part of the journal considers individual artistic practices that are largely linked to the evolving public sphere through various modes - culture, history, social and politics. These connections and associations occur either within nation-states or inter-Asia.

Ceren Özpinar's 'The Istanbul Biennial and the reproduction of the urban public space' discusses the significance of venues and locations of the Istanbul Biennial. The article examines the indirect effect of the Istanbul Biennale, in which they organize, reproduce and change the way both the audience and diverse urban groups relate to the urban public space and the city of Istanbul in general. Özpinar discusses how the choices of venue and location for the Biennale regulate the urban public space, visitors' relation to the city and their exhibition experience. Abdullah's discussion on Malaysian art posited what the author terms as the 'alternative' practices. The paper examines the establishment of alternative art groups/collectives and spaces, proliferation of art festivals and the various community-engaged art projects that have proliferated in Malaysia since the late 1990s.

The papers in the second part of the journal examine practices by Tisna Sanjaya, Cao Fei and Lee Wan, examining how these artists derived their art practice based on the local socio-political and socio-cultural contexts. In 'Art is capital: Between cultural memory and the creative industry', Edwin Jurriëns examines Tisna Sanjaya's eco-aesthetics by addressing the interconnections of Tisna Sanjaya's works on virtual, material and natural environments. The author focuses and frames his analysis based on the jeprut, a form of performance art from West Java, Indonesia. Jurriëns puts forth his arguments by analysing the artists jeprut-inspired print-making, painting, installation art, performance art, television drama and cultural centre. Jurriëns argues, the jeprut-inspired practice can be seen as an indirect complement and corrective measures to the rapid expansion of the creative industry in Indonesia.

In 'The politics of aesthetics, space, and community: An analysis of Same Old, Brand New by Cao Fei', Snels analyses the site-specific video artwork entitled Same Old, Brand New by Chinese artist Cao Fei. Snels examines the work that was exhibited in Hong Kong during Art Basel 2015 - in regard to the context of the Umbrella Revolution. The author argues that artists like Cao Fei have found subtle ways to create political art, to engage the public 
with politics, to disrupt political hegemony, to go beyond the boundaries of art institutions and to produce ungovernable communities that may evade identity politics.

In the investigation and the analysis on the Made-In series produced by Lee Wan, Young Ji Lee discusses the artworks in the context of the spatial movement of the source of each commodity as researched by the artist. Lee Wan's thought-provoking performance or process art, Lee argues, suggests that these works are not merely artwork but most importantly, a kind of art that questions the inevitable global market economy that depends on cheap labour and mass production amid the rapidly expanding transnational circulation of capital.

On top of these articles, Eileen Legaspi shares with us her views and insights on the relationship of art and the community in the Philippines in an online interview with the editor. Legaspi shares her views on art practices that occur within the community, either through the process of art-making that involves the community itself or artists whose artworks are made and produced within the community.

This volume also comes with four exhibition reviews - the first, on an exhibition entitled Passion and Procession: Art from the Philippines at the Art Gallery of New South Wales, Sydney by Soo-Min Shim; and second, a review of the symposium for the exhibition So You See Me at the University of Dundee, Dundee. Jes Fernie reviews Play the City Now or Never!, a mobile app released in 2017 that was researched and developed by Helen Stratford and Idit Nathan. The game application, in a way, can be asserted as a way to reclaim the public realm of East Anglian streets. The last review by Nora Silva scrutinizes the exhibition by Finn Thomson If It Starts to Fall, Move Out the Way at Gibberd Gallery in Harlow Town, Essex, which focuses or examines the state of public sculpture of New Towns such as Harlow.

The papers and interviews in this issue show that the local and global are relative concepts and it is more a matter of one's perspective. Ideas, either in the realm of art-making or as an embodiment of the art-world in general, are always contingent to and dependent on each other. Globalization, mobilization and technologies enable art, artistic practices and the art world to be investigated in the larger milieu of regional and international network. Nevertheless, as discussed in some of these papers, the local culture and context are still in place and are still the core ideas in artistic practice.

Sarena Abdullah has asserted her right under the Copyright, Designs and Patents Act, 1988, to be identified as the author of this work in the format that was submitted to Intellect Ltd. 


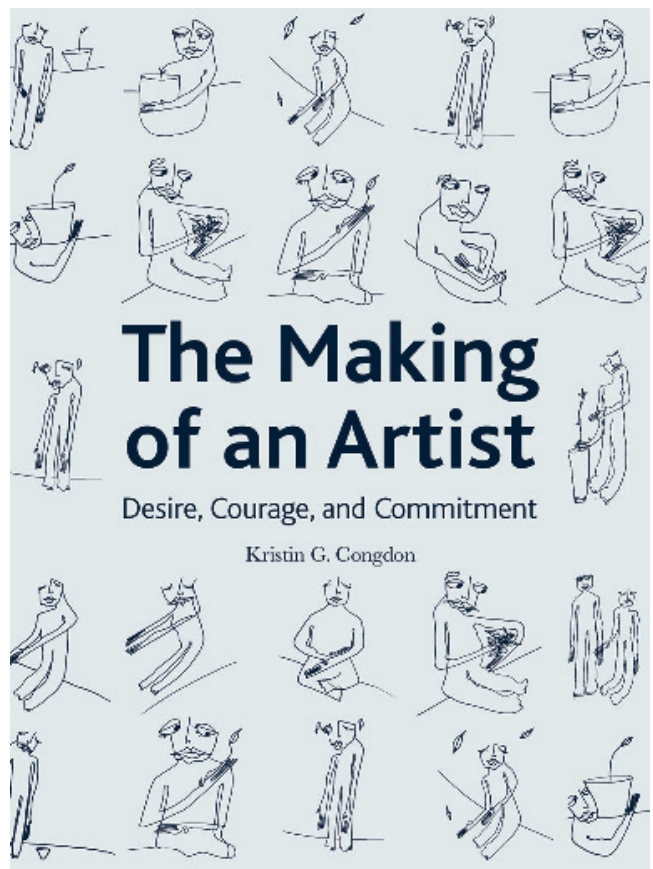

\section{The Making of an Artist}

Desire, Courage and Commitment

By Kristin G. Congdon

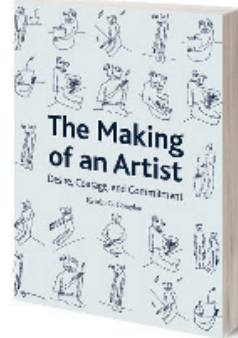

ISBN 978-1-78320-851-7 264 pp |£20, \$26.50

Paperback | Spring 2018 $230 \times 170 \mathrm{~mm}$ eBook available
What drives an artist to create? And are there common traits that successful artists possess? In The Making of an Artist, Kristin G. Congdon draws on her years of studying and teaching art at all levels - from universities to correctional settings - to identify three traits that are regularly found in successful artists: desire, courage and commitment. In this collection Congdon explores each of those traits, as well as giving ethnographic case studies of six visual artists from diverse backgrounds whose practices embody their personal and cultural heritages. Marrying the work of biography, journalism, sociology and psychology, the book opens up the often mysterious process of making art, showing us how those characteristics play into it, as well as how other factors, such as trauma, madness, class and gender, affect the ways that people approach the creative process. Powerfully insightful and fully accessible, The Making of an Artist will be an invaluable resource for practicing artists, those just setting out on artistic careers and art teachers alike. 